\title{
Identification, Characterization, and Molecular Detection of Alfalfa mosaic virus in Potato
}

\author{
H. Xu and J. Nie
}

Canadian Food Inspection Agency, Charlottetown Laboratory, 93 Mount Edward Road, Charlottetown, PEI, C1A 5T1, Canada. Accepted for publication 10 June 2006.

\begin{abstract}
Xu, H., and Nie, J. 2006. Identification, characterization, and molecular detection of Alfalfa mosaic virus in potato. Phytopathology 96:12371242 .

Alfalfa mosaic virus (AMV) was detected in potato fields in several provinces in Canada and characterized by bioassay, enzyme-linked immunosorbent assay, and reverse-transcription polymerase chain reaction (RT-PCR). The identity of eight Canadian potato AMV isolates was confirmed by sequence analysis of their coat protein (CP) gene. Sequence and phylogenetic analysis indicated that these eight AMV potato isolates fell into one strain group, whereas a slight difference between Ca175 and the other Canadian AMV isolates was revealed. The Canadian AMV iso-

lates, except Ca175, clustered together among other strains based on alignment of the $\mathrm{CP}$ gene sequence. To detect the virus, a pair of primers, AMV-F and AMV-R, specific to the AMV CP gene, was designed based on the nucleotide sequence alignment of known AMV strains. Evaluations showed that RT-PCR using this primer set was specific and sensitive for detecting AMV in potato leaf and tuber samples. AMV RNAs were easily detected in composite samples of 400 to 800 potato leaves or 200 to 400 tubers. Restriction analysis of PCR amplicons with SacI was a simple method for the confirmation of PCR tests. Thus, RT-PCR followed by restriction fragment length polymorphism analysis may be a useful approach for screening potato samples on a large scale for the presence of AMV.
\end{abstract}

Alfalfa mosaic virus (AMV) is the type member of the genus Alfamovirus in the Bromoviridae family of plant viruses. The genome of AMV consists of three single-stranded RNA molecules of plus-sense polarity, conventionally numbered RNA 1 to 3 in order of decreasing size. RNA 1 and 2 encode viral replicase proteins P1 and P2, respectively (3). Viral movement protein (MP) is translated directly from RNA $3(8,14,24)$. The viral coat protein (CP) gene located downstream of the MP gene in RNA 3 is translated via a subgenomic RNA, RNA $4(3,5,25,27)$. All RNAs have a cap structure at the $5^{\prime}$ end and a t-RNA-like structure at the $3^{\prime}$ end $(4,6,9)$.

AMV has a very wide host range. This virus can naturally infect many herbaceous and some woody plant hosts ( 150 species in 22 families) and is transmissible to over 430 species of 51 dicotyledonous families (12). AMV can cause various mosaics, mottles, and malformations in alfalfa (Medicago sativa), yellowing of leaves in pea (Pisum sativum), calico and tuber necrosis in potato (Solanum tuberosum), and various symptoms in tobacco (Nicotiana tabacum) $(11,12)$. Sixteen species of aphids, including Myzus persicae, can transmit AMV in a nonpersistent manner $(13,15)$. AMV also can be transmitted through potato pollen and true seed (26). Based on the differential reaction on one or two indicator species, AMV isolates have been classified into many strains or variants $(10,12)$. Nucleotide sequences of some strains have been determined and the genome structures and functions of most of the genes identified have been revealed $(6,7,19,21$, $22,25,28,29)$

AMV can cause problems in potato in some regions where vectors easily move into potato fields from a reservoir host, particularly if a tuber necrosis-causing strain is involved (13). Potato tuber necrosis caused by AMV resembles that caused by the

Corresponding author: H. Xu; E-mail address: xuh@inspection.gc.ca

DOI: 10.1094/PHYTO-96-1237

(c) 2006 Her Majesty The Queen in Right of Canada (Canadian Food Inspection Agency). All rights reserved. Use without permission is prohibited. nematode-transmitted Tobacco rattle virus (TRV, a Tobravirus), Spongospora subterranea-transmitted Potato mop-top virus (PMTV, a Pomovirus), and the potato tuber necrotic strain of $\mathrm{Po}$ tato virus $Y$ (PVY ${ }^{\mathrm{NTN}}$, a Potyvirus) (13). Potato leaf symptoms caused by AMV easily can be confused with those induced by PMTV and Potato aucuba mosaic virus (PAMV, a Potexvirus) (13). AMV is present in potato in Canada and can cause calico symptoms of bright yellow blotching or mottling of leaflets (11). More detailed identification and characterization of Canadian AMV potato isolates and their comparison to AMV strains from other countries will lead to a better understanding of the similarities and differences between AMV potato isolates and will help to design a proper approach for the detection and management of this virus in Canadian potato plants.

Enzyme-linked immunosorbent assay (ELISA), nucleic acid hybridization, and bioassay using Phaseolus vulgaris and Chenopodium amaranticolor or $C$. quinoa have been evaluated $(1,10,20)$ for the diagnosis of AMV. ELISA and bioassay currently are used for the diagnosis of AMV in potato (13). Transmission electron microscopy (TEM) is also a useful tool for the identification of an Alfamovirus based on the shape of viral particles. Reverse-transcription polymerase chain reaction (RT-PCR), developed for screening potato samples for the presence of several viruses, has many advantages over ELISA and bioassay $(17,18,23,30,31)$. RTPCR followed by restriction digestion has proven to be a simple, rapid, and specific procedure for the detection and identification of PMTV, PVY ${ }^{\mathrm{N}}$, and PVY ${ }^{\mathrm{NTN}}$ in potato leaves and tubers $(30,31)$. For the screening of potato leaf and tuber samples for the presence of AMV, it is necessary and important to adopt RT-PCRbased procedures that are more sensitive and specific than most of the diagnostic methods currently employed, such as ELISA. This is relatively easy to do so since sequences of many AMV strains have been determined and are available in public databases.

To develop PCR-based technology for specific and sensitive detection of AMV in potato tissues, we designed a set of primers based on sequence alignment of known AMV strains and developed an RT-PCR procedure. Restriction fragment length polymor- 
phism (RFLP) was applied to confirm the identity of PCR amplicons. AMV isolates detected from Canadian potato fields were characterized using a combination of methods involving serological, molecular, and biological tests. In this article, we report on the efficacy of the various methods employed for detecting, confirming, and verifying the presence of AMV in potato samples. We also report the similarity of the $\mathrm{CP}$ gene sequence between the Canadian AMV potato isolate and AMV isolates from other countries.

\section{MATERIALS AND METHODS}

Potato samples. Leaf samples (Table 1) collected between 2003 and 2004 from plants showing bright yellow blotching or mottling (calico) symptoms on leaflets in potato fields in several provinces in Canada were confirmed to be positive for AMV by initial ELISA, RT-PCR, and RFLP tests. These samples were further characterized by bioassay, TEM, and sequence analysis of the $\mathrm{CP}$ gene. One AMV isolate (AMV Ca175) (Table 1) received in 2003 as a leaf sample from an experimental field plot of potato in Ontario, Canada was characterized and its identity confirmed by the above-mentioned tests. AMV Ca175 then was used throughout this study as a reference isolate. Leaves and tubers of healthy potato plants were used as negative controls in all tests.

Potato leaves were kept at $4^{\circ} \mathrm{C}$ upon arrival at the laboratory. All leaves collected from one plant were combined (up to 25 leaves) into one composite sample. Leaf sap was extracted using a Roller Press (Pollahne, Meku, Germany) and subjected to ELISA and RT-PCR tests as described below. Unused sap was kept at $-20^{\circ} \mathrm{C}$ if it was not used within $12 \mathrm{~h}$. A second aliquot of the sap from RT-PCR-positive samples was retested to confirm the initial results. All PCR amplicons were subjected to restriction digestion using endonuclease SacI (described below) and the RFLP pattern was used to determine whether they matched AMV patterns. Positive leaf samples then were subjected to bioassay (described below).

Bioassay. Leaf sap from AMV-positive samples based on initial ELISA and RT-PCR tests was inoculated onto healthy potato (Russet Burbank) and indicator (C. quinoa) plants. Leaf sap was diluted (1:5) in phosphate buffer $(0.1 \mathrm{M}, \mathrm{pH} 7.2)$ and inoculated onto leaves of potato and $C$. quinoa plants by rubbing carborundum-dusted leaves. Inoculated plants were grown in a greenhouse at 18 to $22^{\circ} \mathrm{C}$ and observed every 2 days for calico symptoms on potato, and local lesions or systemic chlorotic and necrotic flecking on $C$. quinoa. All inoculated plants (regardless of whether or not symptoms developed) were tested for AMV by ELISA, TEM, RT-PCR, and RFLP. Progeny tubers produced on inoculated potato plants were examined for external and internal necrotic symptoms at harvest time and during storage. All progeny tubers were tested by RT-PCR followed by RFLP analysis to identify AMV sequence.

ELISA. Potato tubers and leaves as well as indicator plants were screened for the presence of AMV by a standard doubleantibody sandwich ELISA using commercial coating antibody, conjugate, positive control, and all necessary reagents from Adgen Phytodiagnostics (Auchincruive, UK), following the procedures recommended by the supplier. Tuber or leaf tissues were homogenized in $1 \times$ phosphate buffer containing $0.02 \%$ $\mathrm{NaN}_{3}, 0.1 \%$ Tween 20 , and $0.1 \%$ skim milk powder $(\mathrm{pH} 7.4)$ at a sample:buffer ratio of 1:5, and $100 \mu \mathrm{l}$ of extracted sap was loaded in duplicate on microtiter plates. A panel of positive, negative, and buffer controls, in addition to the controls supplied with the kit, were included on each plate. An absorbance value at $405 \mathrm{~nm}$ of $2.5 \times$ the healthy control reading was used as the positive threshold; however, if absorbance of the healthy control was $<0.040$, a positive threshold of 0.100 was used.

TEM. To examine virus particles by TEM, leaves from the grow-out plants and inoculated potato plants were submitted to the Centre for Plant Health, Sidney, BC, Canada. The presence of AMV-like particles was determined by immunocapture from leaf dips, negative staining, and visualization with a TEM (Hitachi H7100).

RT-PCR test. For each sample, $100 \mu \mathrm{l}$ of sap was treated with the Tri-Reagent (Molecular Research Center, Inc, Cincinnati) according to the procedures described by the manufacturer. Subsequently, the RNA was extracted with chloroform, precipitated with isopropanol, washed with ethanol, and resuspended in $25 \mu \mathrm{l}$ (for tuber samples) or $100 \mu \mathrm{l}$ (for leaf samples) of RNase-free and DNase-free water as described previously (30). RNA extracts from foliage of potato plants infected with other viruses or viroids, including: PMTV, PAMV, TRV, PVY common strain $\left(\mathrm{PVY}^{\mathrm{O}}\right), \mathrm{PVY}^{\mathrm{N}}$ strain, Potato virus $M$ (PVM, a Carlavirus), Potato leafroll virus (PLRV, a Polevirus), Potato virus X (PVX, a Potexvirus), and potato spindle tuber viroid (PSTVd, type species of Pospiiviroid), also were included in RT-PCR tests to determine primer specificity. RNA extracts from leaves and tubers of healthy potato plants were used as negative controls. A reaction containing no cDNA template was included in all PCR tests as a blank control.

Two sets of primers (Table 2) were designed in this study for RT-PCR amplification of AMV RNA based on the alignment of $\mathrm{CP}$ gene sequences of known AMV strains obtained from the NCBI website (Table 3 provides references and GenBank accession number of each strain). Primers AMV-F and AMV-R were

TABLE 1. Identification of Alfalfa mosaic virus (AMV) in potato samples ${ }^{\mathrm{a}}$

\begin{tabular}{|c|c|c|c|c|c|c|}
\hline AMV samples & Potato cultivar & Province $^{b}$ & Chenopodium quinoa & Potato plants ${ }^{\mathrm{c}}$ & ELISA $^{d}$ & PCR/RFLPe \\
\hline Ca175 & Unknown & Ontario & $\mathrm{LL}, \mathrm{SC}$ & $\mathrm{C}$ & $+/+$ & $+/+$ \\
\hline $\mathrm{Ca} 325$ & Unknown & New Brunswick & LL, SC & $\mathrm{C}$ & $-/+$ & $+/+$ \\
\hline $\mathrm{Ca} 375$ & Miriam & Alberta & LL, SC & $\mathrm{C}$ & $+/+$ & $+/+$ \\
\hline Ca399 & Andovor & New Brunswick & $\mathrm{LL}, \mathrm{SC}$ & $\mathrm{C}$ & $+/+$ & $+/+$ \\
\hline $\mathrm{Ca} 400$ & Kennebec & New Brunswick & LL, SC & $\mathrm{C}$ & $+/+$ & $+/+$ \\
\hline Ca401 & Red Pontiac & New Brunswick & LL, SC & $\mathrm{C}$ & $+/+$ & $+/+$ \\
\hline $\mathrm{Ca} 402$ & Russet Burbank & New Brunswick & LL, SC & $\mathrm{C}$ & $+/+$ & $+/+$ \\
\hline Ca468 & Unknown & New Brunswick & $\mathrm{LL}, \mathrm{SC}$ & $\mathrm{C}$ & $-/+$ & $+/+$ \\
\hline Ca508 & Unknown & Ontario & LL, SC & $\mathrm{C}$ & $+/+$ & $+/+$ \\
\hline Ca518 & Unknown & Ontario & LL, SC & $\mathrm{C}$ & $+/+$ & $+/+$ \\
\hline $\mathrm{Ca} 616$ & Unknown & Ontario & LL, SC & $\mathrm{C}$ & $+/+$ & $+/+$ \\
\hline
\end{tabular}

${ }^{a}$ LL: local lesion; SC: systemic chlorotic spots and necrotic flecking; C: Calico symptom; +: positive result; -: negative result.

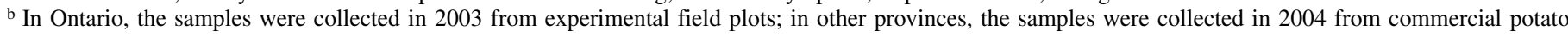
fields.

c Potato cv. Russet Burbank.

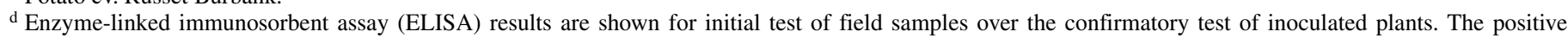
threshold for ELISA was 0.1 .

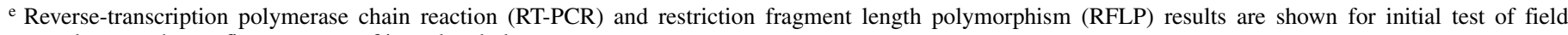
samples over the confirmatory test of inoculated plants. 
used for RT-PCR amplification to detect AMV in potato leaf and tuber samples. The primer set of AMV-F2 and AMV-R2 was designed to amplify the entire CP gene of AMV RNA 3 and the amplicons were submitted for sequencing in both directions using the same primer set (described below).

First-strand cDNA synthesis was carried out using Moloney Murine Leukemia Virus (M-MLV) reverse transcriptase (Invitrogen Canada, Burlington, Canada) using the antisense primer. Two-step RT-PCR was performed according to the procedures described previously $(30,31)$. The temperature regime for amplification reactions was as follows: initial denaturation for $5 \mathrm{~min}$ at $94^{\circ} \mathrm{C}$, followed by 35 cycles of $95^{\circ} \mathrm{C}$ for $30 \mathrm{~s}, 58^{\circ} \mathrm{C}$ for $30 \mathrm{~s}$, and $72^{\circ} \mathrm{C}$ for 30 seconds. The final extension was at $72^{\circ} \mathrm{C}$ for $7 \mathrm{~min}$. A GeneAmp 9700 thermocycler (Applied Biosystems, Foster City, CA) was used for RT-PCR amplifications. Optimal annealing temperature of primers was determined using a temperature gradient thermocycler (Watman Biometra, Goettingen, Germany). PCR products were separated on a $1.2 \%$ agarose gel, stained with ethidium bromide, and visualized under UV light.

Restriction digestion. Restriction endonuclase SacI (New England Biolabs, Mississauga, ON, Canada) was used to digest all PCR products to confirm the PCR amplification. Based on sequence analysis of known AMV strains, one SacI site (GAGCTC) is present in the region flanked by both primer sets (AMV-F/R or AMV-F2/R2); therefore, AMV PCR products should be digested by $\mathrm{SacI}$ into two fragments. Restriction digestion procedures and conditions were the same as described previously (30). RFLPs were analyzed by agarose gel electrophoresis using $2 \%$ agarose-
1000 (Invitrogen Canada, Burlington, ON, Canada) stained with ethidium bromide and visualized under UV light.

Sequencing. Primer set AMV-F2/R2 generated amplicons of the complete $\mathrm{CP}$ gene of AMV and their sequences were determined from both directions by using the same primer set. PCR products were purified using a QIAquick PCR purification kit (Qiagen Inc., Mississauga, ON, Canada) and the purified PCR products then were submitted for sequencing by the dye terminator cycle sequencing method (York University, Toronto, Canada). Sequences of Canadian AMV potato isolates were compared with AMV sequences in the NCBI database with the program BLAST. Nucleotide and amino acid sequences were aligned using ClustalG (v. 1.1) and GeneDoc (16). The phylogenetic relationship of the Canadian potato isolates of AMV and 18 other known AMV strains (Table 3) were deduced using the bootstrap neighbor-joining (N-J) methods (random number generator seed: 111, number of bootstrap trails: 1,000) in the Phylip-formatted Clustal $\mathrm{W}$ (v. 1.82). The trees were visualized and the dendrograms were displayed using the program TreeView (v. 1.5).

\section{RESULTS}

RT-PCR tests. In preliminary tests, amplicons of $351 \mathrm{bp}$ were generated by RT-PCR, using primer set AMV-F/R, from RNA templates extracted from potato leaves infected with AMV isolate Ca175 and 10 other field leaf samples. All PCR amplicons digested by SacI specifically yielded two fragments of the expected sizes of 150 and $201 \mathrm{bp}$ (Table 1; Fig. 1).

TABLE 2. Primer pairs designed for reverse-transcription polymerase chain reaction based on coat protein gene sequence of Alfalfa mosaic virus (AMV) RNA 3

\begin{tabular}{|c|c|c|c|}
\hline Primer pairs & Primer sequence & Location $^{\mathrm{a}}$ & Product size $(b p)$ \\
\hline AMV-F & 5'-CCATCATGAGTTCTTCACAAAAG-3' & $1,188-1,210$ & $\ldots$ \\
\hline AMV-R & 5'-TCGTCACGTCATCAGTGAGAC-3' & $1,518-1,538$ & 351 \\
\hline AMV-F2 & 5'-ATCATGAGTTCTTCACAAAAGAA-3' & $1,190-1,212$ & $\ldots$ \\
\hline AMV-R2 & 5'-TCAATGACGATCAAGATCGTC-3' & $1,838-1,858$ & 669 \\
\hline
\end{tabular}

a Sequence location is based on the complete RNA 3 sequence of AMV-425M (GenBank accession no. K02703) (2).

TABLE 3. Comparison of nucleotide and amino acid sequences of the coat protein of various Alfalfa mosaic virus (AMV) strains

\begin{tabular}{|c|c|c|c|c|c|c|c|}
\hline \multirow[b]{2}{*}{ Strains } & \multicolumn{6}{|c|}{ Identity $(\%)^{\mathrm{a}}$} & \multirow[b]{2}{*}{ GenBank accession no. } \\
\hline & $425 \mathrm{M}$ & KR2 & $\mathrm{L}$ & Caa1 & $\mathrm{Ca} 175$ & Ca508 & \\
\hline $425 \mathrm{M}$ & $\cdots$ & $\ldots$ & $\ldots$ & $\ldots$ & $\ldots$ & $\ldots$ & K02703 \\
\hline $\mathrm{KR} 2$ & $98(98)$ & $\ldots$ & $\ldots$ & $\ldots$ & $\ldots$ & $\ldots$ & AF2944333 \\
\hline $\mathrm{L}$ & $98(97)$ & $96(97)$ & $\ldots$ & $\ldots$ & $\ldots$ & $\ldots$ & K03542 \\
\hline Caa1 & $95(93)$ & $94(93)$ & $95(95)$ & $\ldots$ & $\ldots$ & $\ldots$ & AJ130707 \\
\hline 048 & $98(97)$ & $96(97)$ & $100(100)$ & $95(95)$ & $97(96)$ & $97(95)$ & V00048 \\
\hline $15 / 64$ & $94(94)$ & $93(93)$ & $94(95)$ & $97(98)$ & $93(93)$ & $94(93)$ & $\mathrm{AF} 015717$ \\
\hline $126 \mathrm{~A}$ & $95(95)$ & $94(94)$ & $95(92)$ & $93(90)$ & $95(94)$ & $96(93)$ & AJ130704 \\
\hline $195 \mathrm{AN}$ & $95(94)$ & $95(95)$ & $95(93)$ & $94(92)$ & $95(95)$ & $96(94)$ & AJ130705 \\
\hline 2025 & $100(100)$ & $98(98)$ & $98(97)$ & $95(93)$ & $98(97)$ & 97 (97) & AC_002025 \\
\hline Dac16 & $94(94)$ & $94(93)$ & $95(95)$ & 99 (99) & $94(93)$ & $94(94)$ & AJ130708 \\
\hline Danza & $99(98)$ & 98 (99) & $98(97)$ & $95(93)$ & 99 (99) & 97 (97) & Y09110 \\
\hline F430 & 97 (97) & $96(98)$ & $97(96)$ & $95(93)$ & $97(98)$ & $98(97)$ & AJ130706 \\
\hline KR1 & $98(98)$ & $99(98)$ & $96(97)$ & $94(93)$ & $97(98)$ & $96(95)$ & AF294432 \\
\hline Lyh1 & 95 (94) & $94(93)$ & $95(94)$ & $99(98)$ & $94(93)$ & $95(94)$ & AJ130709 \\
\hline N20 & $98(97)$ & $96(96)$ & 99 (99) & $95(94)$ & $97(95)$ & 97 (95) & AF332998 \\
\hline NZ34 & $98(98)$ & $97(97)$ & $98(97)$ & $95(94)$ & $97(96)$ & $98(97)$ & AF215664 \\
\hline $\mathrm{S}$ & $96(97)$ & $95(96)$ & $96(96)$ & $93(93)$ & $96(95)$ & $95(96)$ & X00819 \\
\hline VUR & 95 (94) & $94(94)$ & $95(95)$ & $98(98)$ & $94(93)$ & $95(94)$ & AF015716 \\
\hline Ca175 & $98(97)$ & $97(98)$ & 97 (96) & $94(93)$ & $\ldots$ & 97 (98) & DQ314750 \\
\hline $\mathrm{Ca} 375$ & $98(98)$ & $97(97)$ & $98(96)$ & $95(94)$ & $97(98)$ & 98 (99) & DQ314749 \\
\hline Ca399 & $97(97)$ & $97(97)$ & $97(95)$ & $95(93)$ & $97(98)$ & $98(98)$ & DQ314751 \\
\hline $\mathrm{Ca} 400$ & $98(98)$ & $97(97)$ & $98(96)$ & $95(94)$ & $97(98)$ & 98 (99) & DQ314752 \\
\hline $\mathrm{Ca} 401$ & 97 (96) & $97(97)$ & $97(95)$ & $95(93)$ & $97(98)$ & $98(97)$ & DQ314753 \\
\hline Ca508 & 97 (97) & $96(96)$ & $97(95)$ & $95(93)$ & $97(98)$ & $\ldots$ & DQ314754 \\
\hline Ca518 & 97 (96) & $96(96)$ & $97(95)$ & $94(93)$ & $97(97)$ & $99(98)$ & DQ341755 \\
\hline Ca616 & 97 (97) & $96(96)$ & $97(95)$ & $95(93)$ & 97 (98) & $100(100)$ & DQ341756 \\
\hline
\end{tabular}

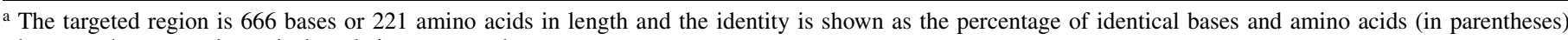
between the two strains or isolates being compared. 
The primers were highly specific only to AMV RNA and they did not produce any amplicon from RNA extracts of healthy potato plants and plants known to be infected with other viruses or viroids. When template RNA extracted from leaf sap of AMV-infected plants was mixed with leaf sap of healthy plants, the expected 351-bp amplicon was obtained from all composite samples (up to 1:1,599) in RT-PCR using primer pair AMV-F/R (Fig. 2A). To evaluate the sensitivity of the RT-PCR for the detection of AMV in dormant tubers, sap from AMV-infected tubers was mixed with sap from healthy tubers in a dilution series from 1:0 to $1: 1,599$. PCR amplicons of $351 \mathrm{bp}$ were detected in all composite tuber samples (up to 1:1,599) and reliable amplification was obtained from the composite tuber samples ranging from 1:0 to $1: 299$ or 1:399 (infected tuber sap/healthy tuber sap, vol/vol) (Fig. 2B). In other evaluations, AMV RNA was detected in highly diluted $(1 / 15,625$ in RNase-free water) RNA preparations (data not shown).

ELISA. Initial ELISA results revealed that 9 of the 11 leaf samples were positive for AMV (Table 1). The two ELISA-negative samples were found to be positive for AMV in initial RT-PCR tests; however, all samples were confirmed to be positive for AMV by all later tests, including ELISA, after inoculation onto potato plants on which they all produced typical calico symptoms (Table 1). Other leaf samples (e.g., 215, 276, 296, 449, and 454) collected from potato plants showing bright yellow mottling to mosaic symptoms from several other provinces, including Nova Scotia, Quebec, and Saskatchewan, also were tested in this study and they were confirmed to be negative for AMV by all tests, but positive for PVX (data not shown).

Confirmatory and verification tests. All samples confirmed to be positive for AMV in the initial RT-PCR screening tests were retested using the same primer set (AMV-F/R) to confirm the validity of the initial test and as a check for false-positive results. In each case, RT-PCR amplicons of 351 bp were obtained and digested into 201- and 150-bp fragments upon treatment with SacI (data not shown). Retested samples that gave the expected RT-PCR and RFLP results were considered as confirmed positive samples. Tissue sap from all positive samples was used to inoculate potato and indicator plants. Typical calico symptoms were observed on inoculated potato plants (Russet Burbank) (Table 1), and inoculated $C$. quinoa plants developed local lesions on the inoculated leaves and systemic chlorotic and necrotic flecking symptoms (Table 1). Subsequently, AMV also was detected by ELISA, RT-PCR, and RFLP (the same as that shown in Table 1) in inoculated plants. The presence of typical AMV particles was

\section{$\begin{array}{llllllllllll}M & 1 & 2 & 3 & 4 & 5 & 6 & 7 & 8 & 9 & 10 & M\end{array}$}

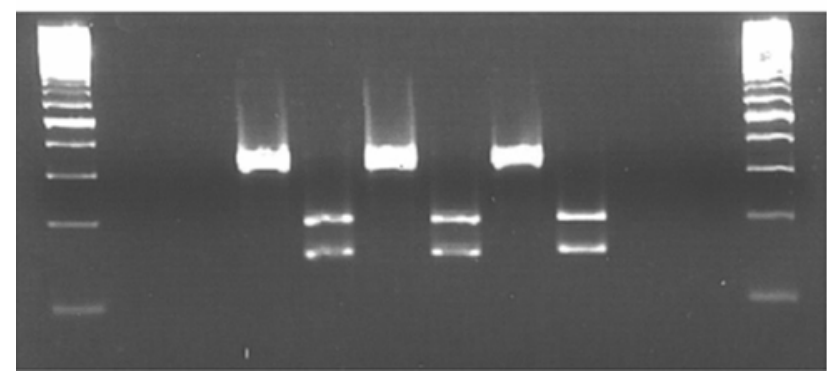

Fig. 1. Reverse-transcription polymerase chain reaction (RT-PCR) products obtained from RNAs extracted from three Alfalfa mosaic virus (AMV)infected potato plants and fragments obtained after digestion of PCR amplicons with restriction endonuclease SacI (lanes 3-8). All RT-PCR tests were performed using primer set AMV-F/AMV-R (lanes 1, 3, 5, 7, 9) followed by SacI digestion (lanes $2,4,6,8,10$ ) for confirmation of amplicon identity. Total RNA extracted from a healthy potato plant was used in the RT-PCR (lane 1) and following restriction test (lane 2) as a negative control. A nontemplate control (using water to replace cDNA) was included in PCR amplification (lane 9) and restriction digestion (lane 10). The size of PCR products was $351 \mathrm{bp}$, which was cut by SacI into two smaller fragments of 201 and $150 \mathrm{bp}$. observed by TEM in samples prepared from potato plants inoculated with AMV isolates. Progeny tubers produced by the inoculated plants did not show any necrotic symptoms (surface or internal) at harvest time or after $>12$ weeks in storage at 4 to $8^{\circ} \mathrm{C}$.

Sequence analysis. Total RNAs extracted from potato leaves confirmed to be positive for AMV by ELISA, bioassay, RT-PCR, and RFLP also were amplified with primer set AMV-F2 and AMV-R2, which flank the entire CP gene of AMV, resulting in PCR amplicons of $669 \mathrm{bp}$. Nucleotide sequence of the CP gene of eight AMV isolates from Canadian potato cultivars (Table 3) were determined. Seven of the eight AMV isolates were closely related $(>98 \%)$ in the nucleotide and amino acid sequences of their CP gene and gene products (Table 3 ). Ca175 was slightly different from the other seven AMV isolates (Table 3). The complete CP gene sequence of all eight Canadian potato isolates of AMV was deposited in NCBI GenBank (accession nos. DQ314749 to DQ314756). AMV Canadian isolates shared $>94 \%$ identical nucleotides and $>93 \%$ identical amino acids with 18 other known AMV strains (Table 3) in their CP gene and the gene product. Despite the fact that the $\mathrm{CP}$ gene and gene products of all analyzed AMV stains or isolates were very similar, it was clear that the sequence of the AMV Canadian isolates more closely matched the sequence of AMV 425M (accession no. K02703), AMV 2025 (accession no. NC_002025)(2), an Italian tomato (Lycopersicon esculentum) isolate of AMV Danza (accession no. Y09110), Italian AMV-F430 (AJ130706), New Zealand AMV-NZ34 (AF215664), and a Korean potato isolate of AMV (KR2, accession no. AF294433) based on the alignment of nucleotide and amino acid sequences (Table 3) and the phylogenetic analysis of nucleotide sequences of AMV strains or isolates (Fig. 3). Canadian AMV isolate Ca175 and Italian AMV Danza shared up to 99\% of identical bases of their CP gene or amino acids of their CP. The Canadian AMV isolates and three other isolates, L (K03542), N20 (AF332998) and 048 (V00048), shared 97\% of identical bases but only $95 \%$ of identical amino acids. The identity among these three AMV isolates (L, N20, and 048) was very high (Table 3 ) and they formed a distinct subgroup as revealed by the phylogenetic analysis (Fig. 3).

\section{DISCUSSION}

In this study, AMV was detected in a potato sample from an experimental farm in the province of Ontario and from potato fields in two other provinces, Alberta and New Brunswick. These AMV isolates were obtained from potato fields located in geographi-

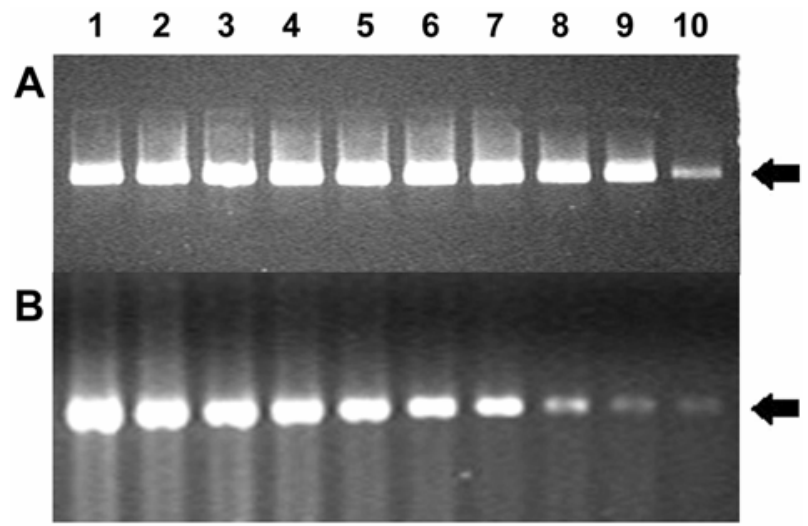

Fig. 2. Sensitivity of reverse-transcription polymerase chain reaction (RT$\mathrm{PCR}$ ) using primer set Alfalfa mosaic virus (AMV)-F/AMV-R for detecting AMV in composite $\mathbf{A}$, leaf and $\mathbf{B}$, tuber samples infected with AMV potato isolate Ca175. RNA templates extracted from mixtures of infected:healthy tissue sap at ratios of 1:0, 1:4, 1:9, 1:24, 1:49, 1:99, 1:199, 1:299, 1:399, 1:799, and 1:1,599 (lanes 1-10, respectively). PCR amplicons of $315 \mathrm{bp}$ are indicated by arrows. 
cally different regions (western, central, and eastern Canada). AMV isolate Ca175 and seven other AMV isolates were characterized in this study by ELISA, bioassay, RT-PCR, RFLP, sequence analysis of the CP gene, and TEM. Data from all the tests positively identified the virus as AMV. Sequence analysis of nucleotides and amino acids showed that these isolates were closely related to each other and there were only slight differences in both nucleotide and amino acid sequences in their CP gene and putative CP. Little genetic variation among them probably indicates that there is only one AMV strain in Canadian potato plants. Phylogenetic analysis based on the nucleotide sequence of the $\mathrm{CP}$ gene showed that Canadian AMV isolates and 18 other known AMV strains might be divided into four or more distinct groups. A moderate level of genetic variation in the $\mathrm{CP}$ gene was revealed among these groups. Variation in the $\mathrm{CP}$ gene nucleotide sequence in up to $7 \%$ of bases and the variation in amino acid sequence of the $\mathrm{CP}$ in up to $10 \%$ of amino acids differentiated at least three distinct subgroups of AMV strains or isolates. AMV isolates 425M (2), Caa1 (19), and Ca508 may be considered as type strains for each of these three groups. The dendrogram (Fig. 3) showed that the Canadian AMV potato isolate Ca175 characterized in this study was closely related to AMV strains from Italy (Danza), Korea (KR2), and the United States (425M and 2025). All the other Canadian AMV potato isolates were closely related to F430 and NZ34. A previous study showed that AMV isolates from France and Italy fell into two distinct subgroups (19). Several strains (15/64, VUR, Lyh1, Caa1, and Dac16) from European countries formed a strain group which is more distantly related to the group of Canadian AMV isolates based on the sequence analysis of their $\mathrm{CP}$ gene.

Two AMV CP-gene-specific primer sets (AMV-F/R and AMVF2/R2) were designed and were highly specific, sensitive, and useful in RT-PCR for detecting and amplifying AMV CP gene sequence from total RNAs extracted from both potato leaves and tubers, including composite samples. The approach of using composite tuber samples will greatly reduce the cost and time associated with RT-PCR for indexing seed potato lots on a large scale for the presence or absence of AMV. Both primer pairs (AMVF/R and F2/R2) designed in this study were specific for AMV RNAs and did not produce amplicons from potato leaves infected with several other viruses or a viroid.

Progeny tubers harvested from inoculated potato plants showed no external or internal necrotic symptoms, although it has been documented that AMV infection can cause potato tuber necrosis $(12,13)$. This might suggest that the AMV isolates detected in Canadian potato plants do not belong to the potato necrotic strain group or that the potato cultivars from which leaf samples were collected and the cultivar used in inoculation tests were not susceptible to the development of tuber necrotic symptoms. Further evaluation of commercial potato cultivars will be important to verify these possibilities. All viruses, including AMV, PLRV, PMTV, TRV, and PVY ${ }^{\mathrm{NTN}}$, that can cause potato tuber necrosis were screened in surveys conducted in recent years in Canada and no tuber necrosis was connected to the infection of AMV $(30,31)$. This supports the conclusion that AMV isolates detected in Canadian potato plants do not cause tuber necrotic diseases of common potato cultivars widely used in Canada.

Analysis of PCR amplicons based solely on molecular mass on agarose gels may result in false-positive conclusions. RFLP analysis of PCR amplicons was used as a confirmation of amplicon identity, proof that the amplicons indeed were derived from AMV RNAs. A single SacI site was confirmed in the region flanked by both primer sets in the CP gene of all AMV strains and the Canadian AMV isolates analyzed in this study. RT-PCR using primer set AMV-F/R followed by RFLP provided a rapid, sensitive, and reliable detection for screening potato tubers.

In summary, AMV isolates were detected in potato plants in Canada and characterized at the serological, biological, and molecular level in this study, and their genetic relationships with other known AMV strains were established. RT-PCR and RFLP protocols were developed for the detection of AMV in potato and for the confirmation of PCR results. Composite leaf or tuber samples can be used in the RT-PCR tests to reduce the time and cost needed for screening tubers on a large scale.

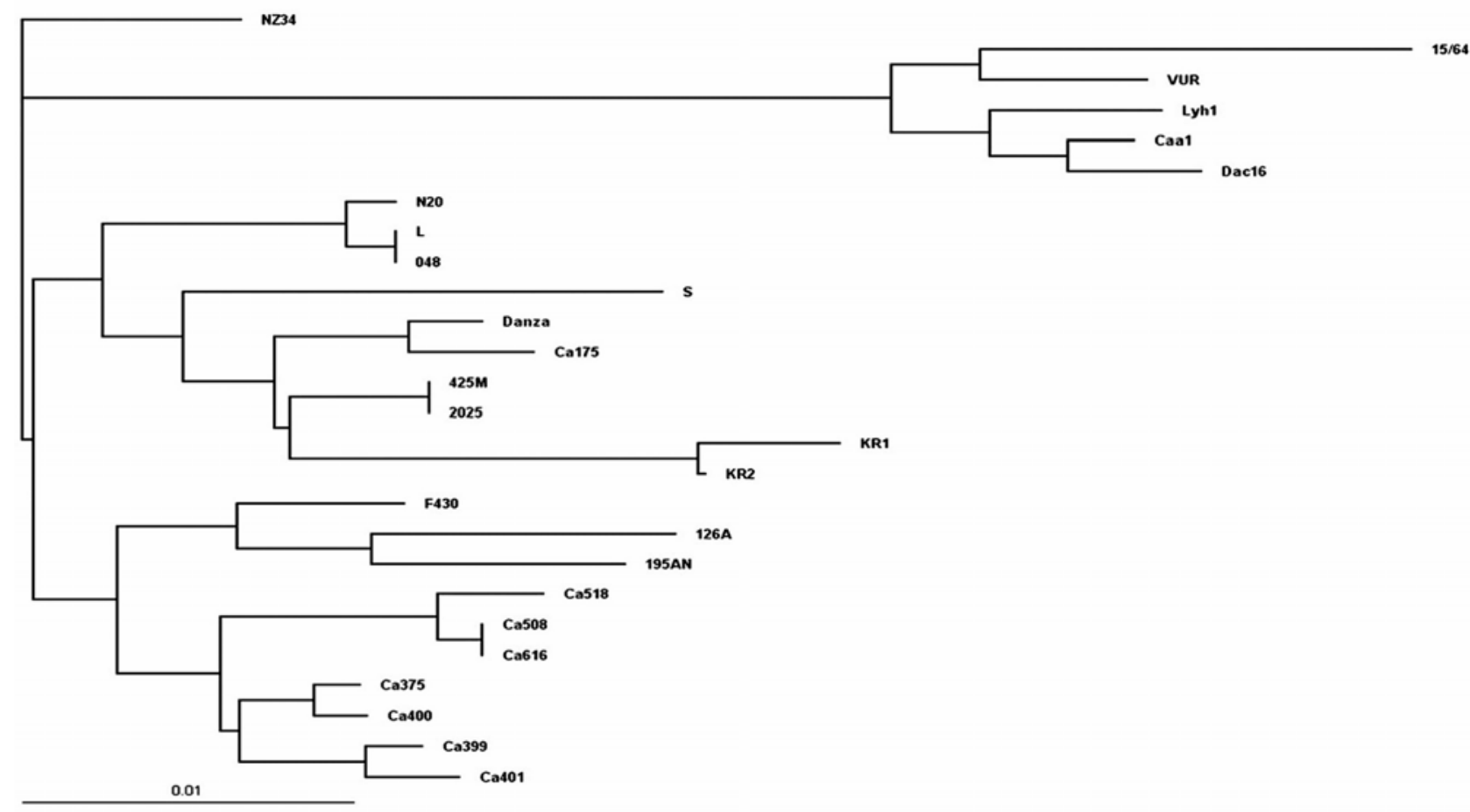

Fig. 3. Phylogenetic dendrogram depicting the relationship of the Canadian Alfalfa mosaic virus (AMV) isolates and other known AMV strains based on alignment of nucleotide sequence of the coat protein gene. The bar indicates the relative evolution distance. 


\section{ACKNOWLEDGMENTS}

We thank J. Gourley, P. Ross, C. Saw, and J. D'Aubin for technical support; S. H. DeBoer for critical review of the manuscript and helpful comments; and C. Masters of the Centre for Plant Health, Sidney, BC, Canada for the electron microscopy work.

\section{LITERATURE CITED}

1. Ahoonmanesh, A., Hajimorad, M. R., Ingham, B. J., and Francki, R. I. B. 1990. Indirect double antibody sandwich ELISA fro detecting Alfalfa mosaic virus in aphids after short probes on infected plants. J. Virol. Methods 30:271-282.

2. Barker, R. F., Jarvis, N. P., Thompson, D. V., Loesch-Fries, L. S., and Hall, T. C. 1983. Complete nucleotide sequence of Alfalfa mosaic virus RNA 3. Nucleic Acids Res. 11:2881-2891.

3. Bol, J. F. 1999. Alfalfa mosaic virus and ilarviruses: Involvement of coat protein in multiple steps of the replication cycle. J. Gen. Virol. 80:10891102.

4. Bol, J. F., van Vloten-Doting, L., and Jaspars, E. M. J. 1971. A functional equivalence of top component $a$ RNA and coat protein in the initiation of infection by Alfalfa mosaic virus. Virology 46:73-85.

5. Brederode, F. T., Koper-Zwarthoff, E. C., and Bol, J. F. 1980. Complete nucleotide sequence of Alfalfa mosaic virus RNA 4. Nucleic Acids Res. 8:2213-2223

6. de Graaff, M., Houwing, C. J., Lukacs, N., and Jaspars, E. M. 1995. RNA duplex unwinding activity of Alfalfa mosaic virus RNA-dependent RNA polymerase. FEBS Lett. 371:219-222.

7. de Graaff, M., Man In T Veld, M. R., and Jaspars, E. M. 1995b. In vitro evidence that the coat protein of Alfalfa mosaic virus plays a direct role in the regulation of plus and minus RNA synthesis: Implications for the life cycle of alfalfa mosaic virus. Virology 208:583-589.

8. Erny, C., Schoumacher, F., Jung, C., Gagey, M.-J., Godeefroy-Colburn, T., Stussi-Garaud, C., and Berna, A. 1992. An N-proximal sequence of the Alfalfa mosaic virus movement protein is necessary for association with cell walls in transgenic plants. J. Gen. Virol. 73:2115-2119.

9. Gunn, M. R., and Symons, R. H. 1980. Sequence homology at the 3'termini of the four RNAs of Alfalfa mosaic virus. FEBS Lett. 109:145150 .

10. Hajimorad, M. R., and Francki, R. I. B. 1988. Alfalfa mosaic virus isolates from lucerne in South Australia: Biological variability and antigenic similarity. Ann. Appl. Biol. 113:45-54.

11. Howard, R. J., Garland, J. A., and Seaman, W. L. (eds.) 1994. Page 241 in: Diseases and Pests of Vegetable Crops in Canada. The Canadian Phytopathological Society and Entomological Society of Canada.

12. Jaspars, E. M., and Bos, L. 1980. Alfalfa mosaic virus. No. 229 in: Descriptions of Plant Viruses. Commonw. Mycol. Inst./Assoc. Appl. Biol., Kew, England.

13. Jeffries, C. J. 1998. FAO/IPGRI Technical Guidelines for the Safe Movement of Germplasm: Potato No. 19. Food and Agriculture Organization of the United Nations, Rome/International Plant Genetic Resources Institute, Rome.

14. Langereis, K., Mugnier, M.-A., Cornelissen, B. J. C., Pink, L., and Bol, J. F. 1986. Variable repeats and poly (A)-stretches in the leader sequence of
Alfalfa mosaic virus RNA 3. Virology 154:409-414.

15. McLaughlin, M. R. 1991. A greenhouse method for aphid inoculation of Alfalfa mosaic virus in white clover by co-culture of virus, vector, and clover. Page 318 in: Aphid Plant Interaction: Populations to Molecules. D. C. Peters, J. A. Webster, and C. S. Chloubers, eds. Okla. Agric. Exp. Stn. Stillwater, OK.

16. Nicholas, K. B., and Nicholas, H. B., Jr. 1997. Gene Doc: A tool for editing and annotating multiple sequence alignments. Distributed by author. Online Publication. www.psc.edu/biomed/genedoc.

17. Nie, X., and Singh, R. P. 2002. A new approach for the simultaneous differentiation of biological and geographical strains of Potato virus $\mathrm{Y}$ by uniplex and multiplex RT-PCR. J. Virol. Methods 104:41-54.

18. Nie, X., and Singh, R. P. 2003. Specific differentiation of recombinant $\mathrm{PVY}^{\mathrm{N}: \mathrm{O}}$ and PVY ${ }^{\mathrm{NTN}}$ isolates by multiplex RT-PCR. J. Virol. Methods 113:69-77

19. Parrella, G., Lanave, C., Marchouz, G., Sialer, M. M., Di Franco, A., and Gallitelli, D. 2000. Evidence for two distinct subgroups of Alfalfa mosaic virus (AMV) from France and Italy and their relationships with other AMV strains (brief report). Arch. Virol. 145:2659-2667.

20. Pesic, Z., and Hiruki, C. 1988. Comparison of ELISA and dot-hybridization for detection of Alfalfa mosaic virus in alfalfa pollen. Can. J. Plant Pathol. 10:116-122.

21. Pinck, L., and Pinck, M. 1979. Sequence homology at the 3 '-ends of Alfalfa mosaic virus RNAs. FEBS Lett. 107:61-65.

22. Ravelonandro, M., Pinck, M., and Pinck, L. 1984. Complete nucleotide sequence of RNA 3 from Alfalfa mosaic virus, strain S. Biochimie 66:395-402.

23. Robinson, D. J 1992. Detection of Tobacco rattle virus by reverse transcription and polymerase chain reaction. J. Virol. Methods 40:57-66.

24. Stussi-Garaud, C., Garaud, J.-C., Berna, A., and Godefroy-Colburn, T. 1987. In situ location of an Alfalfa mosaic virus non-structural protein in plant cell walls: Correlation with virus transport. J. Gen. Virol. 68:17791784.

25. Tenllado, F., and Bol, J. F. 2000. Genetic detection of the multiple functions of Alfalfa mosaic virus coat protein in viral RNA replication, encapsidation, and movement. Virology 268:29-40.

26. Valkonen, J. P. T., Pehu, E., and Watanabe, K. 1992. Symptom expression and seed transmission of Alfalfa mosaic virus, Potato yellowing virus and Potato yellowing virus SB-22 in Solanum brevidens and S. tubersosum. Potato Res. 35:403-410.

27. van der Vossen, E. A. G., Neeleman, L., and Bol, J. F. 1994. Early and late functions of Alfalfa mosaic virus coat protein can be mutated separately. Virology 202:891-903

28. van der Wel, N. N., Goldbach, R. W., and van Lent, J. W. M. 1998. The movement protein and coat protein of Alfalfa mosaic virus accumulate in structurally modified plasmodesmata. Virology 244:322-329.

29. Van Rossum, C. M. A., Neeleman, L., and Bol, J. F. 1997. Comparison of the role of 5' terminal sequences of Alfalfa mosaic virus RNAs 1, 2, and 3 in viral RNA replication. Virology 235:333-341.

30. Xu, H., DeHaan, T.-L., and De Boer, S. H. 2004. Detection and confirmation of potato mop-top Pomovirus in potatoes produced in the United States and Canada. Plant Dis. 88:363-367.

31. Xu, H., Nie, J., and De Boer, S. H. 2005. Differentiation and molecular detection of Canadian necrotic strains of potato virus Y. Can. J. Plant Pathol. 27:1-7. 